\title{
Is Austrian budgetary policy still "political"? A cross-time comparison of budget speeches ${ }^{1}$
}

\author{
Johannes Karremans, Johann Kaltenleithner
}

University of Salzburg

johannes.karremans@sbg.ac.at

\begin{abstract}
This paper investigates whether and how the democratic feedback loop between the government and parliament has been affected in Austrian budgetary policy-making. The question stems from the observation that since 2009 the budgetary policymaking process has been substantially affected by both national and European reforms, with some scholars arguing that budgetary policy today has become a bureaucratic rather than a political exercise. Through a comparative content analysis of finance ministers' budget speeches we show that this is not the case and that instead - compared to the past - the share of political discourse has remained substantial. Furthermore, we find that today Austrian governments present the parliament with more detailed information about their planned expenditures and taxations, and that these plans are linked more strongly to the governing parties' manifestos rather than the European country-specific recommendations.
\end{abstract}

\section{Keywords}

accountability; Austrian politics; budgetary policy; European Semester; party-government

\section{Ist die österreichische Budgetpolitik noch “politisch"? Ein zeitübergreifender Vergleich von Budgetreden}

\section{Zusammenfassung}

Dieser Beitrag stellt den Anspruch, zu ergründen, ob und auf welche Weise die demokratische Rückkopplungsschleife zwischen Regierung und Parlament im Bereich der österreichischen Budgetpolitik eine Beeinträchtigung erfahren hat. Diese Frage rührt von der Beobachtung her, dass der budgetpolitische Entscheidungsprozess seit 2009 erheblichen Änderungen durch sowohl nationale als auch europäische Reformen unterzogen wurde. Einige WissenschaftlerInnen argumentieren in diesem Zusammenhang, dass Budgetpolitik heute zu einem verstärkt bürokratischen anstatt politischen Prozess verkommen sei. Durch eine vergleichende Inhaltsanalyse der Budgetreden österreichischer FinanzministerInnen zeigen wir, dass dies nicht der Fall ist und dass der Anteil politischen Diskurses - verglichen mit der Vergangenheit - vielmehr weiterhin beträchtlich ist. Darüber hinaus stellen wir fest, dass österreichische Regierungen das Parlament heutzutage mit detaillierteren Informationen über ihre geplanten Ausgaben und Steuereinnahmen versorgen und dass diese Vorhaben stärker an die Wahlprogramme der Regierungsparteien als an die länderspezifischen Empfehlungen der EU anknüpfen.

\section{Schlüsselwörter}

Verantwortlichkeit; österreichische Politik; Budgetpolitik; Europäisches Semester; Parteienregierung

The authors have declared that no competing interests exist.

I This research is part of the project „A Comparative Study of Budgetary Discourse in the Eurozone“, funded by the Austrian Science Fund (Grant number M_259I). Johannes Karremans would like to thank the Department of Political Science of the University of Salzburg for hosting this project. Special thanks to Fabian Habersack, who commented on an earlier version of this paper that was presented at the ECPR General Conference 2020. Any errors of course remain our own. 


\begin{abstract}
"Since 1954, there has never been a year in Austria in which the state has not spent more than it took in. [...] In 2019, based on revenues of 79,69 billion Euros and expenditures of 79,15 billion Euros, we will have a positive balance for the first time in 65 years. Once again: This is the turning point in the budgetary policy for Austria."
\end{abstract}

(Hartwig Löger, Nationalrat, 2I March 20I8).

This statement by the Austrian Finance Minister of the Kurz I government crowns almost a decade of budgetary policy, during which Austria - like most Eurozone countries - was committed to reduce its public deficit. During the early years of the 20Ios, the governments of the Eurozone committed themselves to strict fiscal rules and started coordinating their budgetary policies through the process of the European Semester, i.e. the annual cycle of fiscal policy coordination between national governments and European institutions (Doray-Demers/ Foucault 2017; Verdun/Zeitlin 2018). In parallel, between 2009 and 2013, Austria also adopted a reform of its budgetary process that had been designed by its finance ministry in the mid-200os, with the aim of making public budgeting more result-oriented (Steger 20I2; 20IO). This reform is a key example of how state bureaucracy contributes in shaping public policy (Biegelbauer et al. 2015) and makes Austria one of the role models in public budgeting according to international and European standards (OECD 2018; Schoubroeck et al 2019).

The fiscal stringency rules adopted across the Eurozone between the late 2000 s and early 20IOs (DorayDemers/Foucault 2017) have been interpreted by various scholars as evidence of the idea that increasing (European) economic integration leads governments into a fiscal straightjacket in which their room-for-manoeuvre is substantially reduced (Rodrik 2000). Following this logic, after the budgetary reforms of the early 2oros, governments and parliaments no longer have the room to discuss and make distinct political choices that are responsive to domestic political preferences (Mair 20I3; Rose 20I4; Scharpf 20II). The empirical implications of this proposition, however, have remained largely unexplored and seem to be contradicted by the evidence of member states complying only marginally with the country-specific recommendations of the European Semester (Bekker 2016; Mariotto/Franchino 2020). This leaves the question open whether governments' autonomy in budgetary policy-making has been reduced or left unaltered.

2 "Seit 1954 hat es in Österreich kein Jahr gegeben, in dem der Staat nicht mehr ausgegeben hat, als er eingenommen hat. [...] Im Jahr 2019 werden wir mit Einzahlungen von 79,69 Milliarden Euro und Auszahlungen von 79,15 Milliarden Euro erstmals seit 65 Jahren einen positiven Saldo von o,54 Milliarden Euro haben. Noch einmal: Das ist der Wendepunkt in der Budgetpolitik für Österreich."
In an attempt to answer this question, this paper compares the speeches by which Austrian governments presented their budgetary choices to the Nationalrat in the 2009-2017 and the 1992-1997 periods, during which governments were composed of a coalition between Christian- and social-democrats. In addition, this paper investigates whether the key budgetary choices of the 2009-2018 period originate from the governing parties' political programmes or from the European country-specific recommendations. Our analysis reveals that the budgets of the 2oros are by no means less 'political' than the budgets of the 1990s, and that instead during the 2oros governments provide more specific information about their budgetary choices. In line with similar research on budgetary policy in Germany (Karremans $2 \mathrm{O} 2 \mathrm{O}$ ), we find extensive evidence that the political programmes of governing parties play a defining role in shaping budgetary choices. Our findings thus suggest that the quality of the democratic feedback loop has improved rather than worsened.

The paper starts with a description of the Austrian and European budgetary reforms. Subsequently, it discusses the rationale of the comparison between the I990s and 20IOs, and presents the method for identifying budgetary policy-choices and their criteria. The empirical analysis is presented in two parts, with one sub-section comparing the budget speeches of I990s and 20Ios, and one subsection investigating the role of European recommendations and party-programmes in shaping the policy-proposals of the budget speeches. In the Conclusion, we discuss how budgetary policy-making in Austria is shaped by the domestic governing parties, and what this tells us about democratic governance under European economic integration.

\section{Austria's new budgetary policy-process}

The new Austrian budgetary process is largely in line with international standards for budgetary governance, which prescribe that yearly budgets should be embedded in medium-term frameworks and operate top-down, with the formulation of broad fiscal policy-goals at the government level and the allocation of more specific budgetary resources and targets at the lower levels of the public administration (OECD 2018). The reform was approved by the Austrian parliament in 2007 and introduced in two steps in 2009 and 2013. In 2009, a four-year medium-term framework (MTF) was introduced, by which governments are required to set budgetary ceilings that must be enacted into law. Once the MTF has been set, for the subsequent four years governments must comply with these ceilings, irrespective of the electoral cycle. The MTFs are accompanied by a Budget Strategy Report that provides information 
about the budgetary ceilings, which become subject of parliamentary discussion before approval. In 2013 the top-down approach in budgeting was introduced, by which the central government is in charge of setting an overall budgetary framework, which is subsequently made more specific at the lower administrative levels. This new approach - which replaced the previous item budgeting - came together with a result-oriented management of public finances, which requires that outputs and outcomes defined in the annual budget are put into operation (Meszarits/Seiwald 2008).

The reform of the Austrian budgetary policy-making process happened concurrently to the European reform of economic governance, as a consequence of which national parliaments lost the exclusivity of being the main controllers of governments' plans, and obligations were introduced to coordinate national budgetary policy-making with European institutions (Crum 2013; Karremans/Lefkofridi 2020; Verdun/Zeitlin 2018). Under the new framework, national budgets are not only expected to meet the Maastricht criteria of keeping public debt and deficit respectively within the $60 \%$ and $3 \%$ of GDP threshold, but must also take into consideration the country-specific recommendations provided by the European Council. In this new framework, the European Commission has acquired unprecedented powers in coordinating national taxation and spending policies, as it now can sanction member states failing to comply with the European budgetary benchmarks (Laffan 2OI4). In addition, since the beginning of the decade member states have adopted new legislation - often in the form of constitutional laws - to oblige their governments to fulfil to the European budgetary guidelines (Doray-Demers/ Foucault 2017). In Austria, the introduction of MTFs and their related obligations facilitated the fulfilment to European budgetary requirements. Consequently - just as European budgetary rules have been criticized for an excessive focus of fiscal responsibility rather than democratic responsiveness (Mair 2014; Schäfer/Streeck 2013) - similar concerns have also been expressed regarding the Austrian reform (Brandtner et al. 2013).

In the policy-papers of the Austrian Finance Ministry, however, the reform is also presented as an effort to improve the political communication between the government and the parliament (Meszarits/Seiwald 2008). More precisely, the decision of reforming the budgetary process stemmed also from the intention to avoid the doom scenario developed by international experts during the 1990s that national budgetary policy-making would be strictly about registering decisions already pre-taken in other (international) arenas (Schick 2003). Rather than restricting the political debate on budgetary policy, the introduction of a parliamentary discussion on the MTFs was intended to provide a window for the executive and the legislative to discuss the political objectives of the country's budgetary policy. If this aim was achieved, today budgetary policy-making should still be "political", i.e. the discussion of budgetary policy between the government and the parliament should still feature clearly distinct political proposals on behalf of the former, which the latter can support or decline. Such an assessment, however, requires also a comparison across time, through which it is possible to see whether the budgetary policy process is today more or less political than it used to be before the Austrian and European reforms.

\section{Political and economic background (1990s and 2010s)}

In order to make valid comparisons about the political and institutional content of budget speeches across time, it is helpful to maintain at least the political and economic contexts relatively constant (Damhuis/Karremans 2017; Truchlewski 2018). Measuring the political influence to policy-discourse consists in grasping the extent to which - despite various economic and institutional constraints - the ideology of the governing parties is somehow relevant to decisions of the executive (Powell 2004; M. G. Schmidt 1996). Comparisons between different levels of political content may therefore become highly difficult when the ideological composition of government is entirely different from one case to another and when economic and institutional circumstances are excessively non-similar.

The Austrian governments of the 1990-1997 and 2009-2017 periods share some relevant political and contextual similarities. These regard in particular the Vranitzky III, IV and V (1990-1997), the Faymann I and II (2009-2016) and the Kern governments (2016-2017). All cabinets feature a coalition between the Sozialdemokratische Partei Österreichs $(\mathrm{SPÖ})^{3}$ and the Österreichische Volkspartei (ÖVP)4. In these cases, the governing parties share a pro-EU stance and have differing socio-economic views, with the SPÖ being more welfare-oriented and the ÖVP standing for more liberal economic views (Hutter/Kriesi 2019; Kriesi et al. 2012).

During both time-periods, Austrian governments were under strong pressure to meet European budgetary requirements. As a consequence, during both decades budgetary policy was characterized by a progressive reduction of public deficits. In 2009, like in most other European countries, public deficit rose again sharply, beyond the European Union's (EU) allowed threshold of $-3 \%$ of GDP, as a result of the public sector's response to the consequences of the global financial crisis. In the following years - also as a result of the strengthening

3 Social-Democratic Party of Austria 4 Austrian People's Party 
of European budgetary rules (Doray-Demers/Foucault 2017; Laffan 20I4) - the governments of the Eurozone pursued a policy of austerity to consolidate their budgets (Schäfer/Streeck 2013). During the I990s the aim was to meet the - $3 \%$ set by the Maastricht Treaty on Economic and Monetary Union (EMU). In 1995 the deficit was at $-6 \%$ of GDP and the two governing parties, albeit with important differences regarding how, were both committing on reducing the deficit in order to meet the Maastricht criteria and gain access to EMU (Praprotnik 2017, I28-I29). In 1998 the Council determined that Austria had met the convergence criteria, making it eligible for introduction of the Euro (Fischer 200I, 208).

Figure I illustrates the Austrian public deficit levels and the annual growth rates of GDP per capita between 1992 and 20I8. The main cross-time difference between the I990s and 2olos is that the latter time period was marked by the Great Recession, registering the biggest annual decline in economic output of the post-war period. Because of this cross-time difference, the I99os governments may by comparison have more resources to pursue fiscal stimulus policies to cater to their voters than the governments of the 2oros. Nonetheless, the budgetary outlook of the I990s and 2010s runs largely parallel, with an initial high deficit and a subsequent progressive consolidation.

Figure 1: Public deficit in Austria (as \% of GDP, 1995-2018)

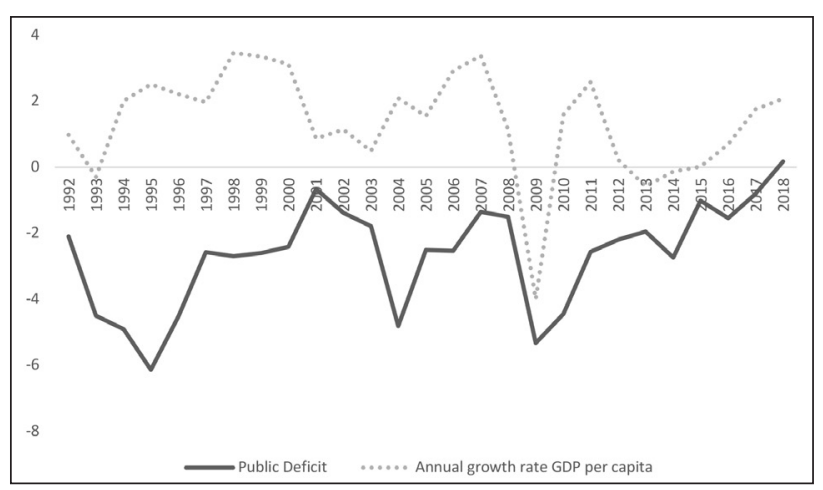

Source Public Deficit: For years 1995-2018, Eurostat (2021). For years 19921994, Statistik Austria (2020) Source Annual growth rate GDP per capita: OECD data.

For our cross-time comparison, we analysed the speeches delivered during the consolidation period. For the I990s these are the speeches delivered between $1992-$ the year Austria formally acknowledged that joining the EU entailed participating in EMU (Nauschnigg 1992, 34I-342) - and 1998, the year in which it formally achieved the budgetary targets. These speeches are compared with the speeches delivered from 2009 - the year in which public deficit rose to $-5 \%$ and in which the MTFs were introduced - until 20I7, when public deficits were again fully in line with the EU criteria.

\section{Research design and methodology}

Despite the reform of the rules governing the budgetary process, both during the I990s and 2010 s finance ministers were expected to appear in front of the parliament on a yearly or - in case of a Doppelbudget ${ }^{5}$ - on a by-yearly basis to present the executive's budgetary policy. These speeches allow the coding of the statements by which governments justify their budgetary policies (Damhuis/ Karremans 20I7; V. A. Schmidt 2008; Veen 2OII). In representative democracies, legitimizing policy-decisions on the basis of political preferences signals that governments emphasize the representative commitments towards their voters: during election campaigns they represented welfare or liberal-oriented views, and in government they are expected to translate these views into policies (Kriesi et al. 2012). Therefore, policy justifications expressing political views are linked to the 'chain of responsiveness' (Powell 2004), which connects citizens' preferences to policy-outputs. At the same time, governments may sometimes recognize that their hands are tied by their institutional commitments, and that therefore their policies should not follow political motives but instead be in line with their institutional responsibilities (V. A. Schmidt 2020).

When categorizing the arguments with which policies are justified, our interest is into whether budgetary choices are justified according to on the one hand socially- or market-oriented views, and on the other according to criteria of financial and institutional responsibilities ${ }^{6}$. Justifications containing socially- and market-oriented arguments politicize budgetary choices by profiling them according to either welfare or liberal-oriented preferences, which also during the 2olos constituted the main structuring themes of political competition (Hutter/Kriesi 2019; Ennser-Jedenastik 2020). The following excerpts provide an example of each of these categories:

"Also with regards to the revenue-related measures, we paid particular attention to social justice. The burden imposed on the various social groups is fair. The contribution of the individual stands in a just proportion to his or her economic capabilities"?

(Viktor Klima, Nationalrat, 20 March 1996, emphasis added)

"[...] we take [financial] pressure off the people with the abolition of the credit contract free. This will directly ease

5 Double budget

6 For the list of speeches coded, please see Appendix I.

7 "Auch bei den einnahmenseitigen Maßnahmen wurde besonders auf soziale Gerechtigkeit geachtet. Die Belastung der verschiedenen sozialen Gruppen ist ausgewogen. Der Beitrag des einzelnen [sic] steht in einem gerechten Verhältnis zu seiner wirtschaftlichen Leistungsfähigkeit." 
the burden on small and medium domestic businesses." (Josef Pröll, 30 November 20I0, emphasis added)

In the first example, the underlined argument justifies the overall tax policy of the government (bold text) as being socially sensitive, i.e. taking into account contributors' financial capabilities. The second example instead presents a more specific policy - the abolition of the credit contract fee - which is justified with an argument about reducing the fiscal pressure for small businesses and the middle classes. In both cases, the policy-justifications are examples of responsiveness towards distinct political preferences: in the former towards principles of social justice and cohesion, in the latter towards principles of entrepreneurship and safeguarding the private sphere. These justification categories - especially when associated with fiscal stimulus policies - signal the autonomy of the government in responding to domestic political preferences (Karremans/Damhuis 2018; Karremans/Lefkofridi 202O; Mair 2013; Scharpf 2OII).

Arguments emphasizing commitments to national or European budgetary rules, instead, signal a commitment to pre-defined rules. Extensive use of these justifications indicates that the government is adhering to a pre-defined budgetary framework, rather than making autonomous decisions. The following passage features two justifications for the same reform-package:

"With this spring's reform package, we have already completed considerable work for general government finances: Not only have we consolidated the federal government's finances in a sustainable way, but we have also reached a national agreement, i.e. together with the states and the municipalities, on the introduction of a debt brake. From 2016 there will be a balanced budget. Not least, this was facilitated by the European rules. With the Fiscal Compact, the European debt brake, the duties of reporting to the European Commission, the obligation to correct excessive deficits and the European consensus to consolidate the budgets, it became possible to take this path together in Austria, too". 9

(Maria Fekter, I6 October 2012, emphasis added)

The first justification is an example of the national institutional commitment to sustainable public finances, and was thus coded as "national finances". The second justification instead emphasizes the compliance with

8 „[... entlasten die Menschen mit der Abschaffung der Kreditvertragsgebühr. Für heimische kleinere und mittlere Unternehmen und den Mittelstand kommt es damit zu einer direkten Entlastung."

9 "Mit dem Reformpaket im heurigen Frühjahr haben wir schon einiges für die gesamtstaatlichen Finanzen erledigt: Wir haben nicht nur auf Seite des Bundes die Finanzen nachhaltig saniert, sondern wir haben auch gesamtstaatlich, das heißt mit Ländern und Gemeinden, eine Schuldenbremse vereinbart. Ab 2016 wird
EU-commitments and was coded as "international commitments".

Besides arguments highlighting responsiveness to political preferences and commitment to institutional responsibilities, governments' budgetary discourse also features a substantial amount of justifications highlighting the commitment to the country's overall well-being, revealing neither a political choice nor a commitment to institutional budgetary thresholds (Karremans 2020). Examples are statements about how the budget serves the country's prosperity or how it contributes to macro-economic indicators. In doing so, these statements do not express a preference for a specific approach to economic policy. Examples of these justifications are the following:

"We also need further impulses for growth so that we can lastingly and sustainably stabilize our country even in difficult times." ${ }^{\text {Io }}$

(Hartwig Löger, Nationalrat, 2I March 2018)

"The federal budget estimate for 1993 is another proof for the continuity and predictability of the successful Austrian economic policy."

(Ferdinand Lacina, Nationalrat, 22 October 1992)

These arguments were coded as "macro-economic", and are distinguished from the market-oriented arguments because they do not reveal a preference for supporting entrepreneurship or private property.

Next to the argument by which governments justify their budgets, another important component of the speeches are the actual policies presented. Budget speeches sometimes present measures that explicitly increase or decrease taxation or expenditure levels, and sometimes present more general policies. In addition, they may sometimes also present EU-level policies, which may consist of either the policies pursued by the Austrian government at EU-level, or EU-level policies that have implications for Austria. To a lesser extent, budget speeches may sometimes also present other type of policies, such as for example administrative reforms. For the purpose of this paper, we thus created five policycategories, namely:

es einen ausgeglichenen Haushalt geben. Nicht zuletzt haben die europäischen Vorgaben dabei Unterstützung geleistet. Mit dem Fiskalpakt, der europäischen Schuldenbremse, den Berichtspflichten an die Kommission, der Verpflichtung, übermäßige Defizite abzubauen, und dem europäischen Konsens, die Haushalte zu konsolidieren, ist es auch in Österreich gelungen, diesen Weg gemeinsam zu beschreiten."

Io "Wir brauchen auch weitere Wachstumsimpulse, damit wir unser Land langfristig und nachhaltig auch in schwierigen Phasen stabilisieren können."

II "Der Bundesvoranschlag 1993 ist ein neuerlicher Beweis für die Kontinuität und für die Berechenbarkeit der erfolgreichen österreichischen Wirtschaftspolitik." 
- General policies: that do not specify whether they involve increases or decreases in expenditure and taxation. The most recurrent example is when the government simply refers to "this year's budget".

- Fiscal consolidation: policies such as expenditure reduction and tax increases, that are in line with the goal of reducing deficits

- Fiscal stimulus: policies such as expenditure increases and tax reductions, that provide resources to socio-economic actors but could potentially increase deficits

- European policies

- Other: including mostly administrative reforms

When cross-tabbing the policy-types and justifications, it becomes visible whether governments tend to propose fiscal stimulus policies with social- or market-oriented arguments, or whether instead they tend to present fiscal consolidation policies and justify them with arguments about national or international budgetary commitments. Following the pessimistic argument about the impact of Austrian budgetary reform and European rules on government autonomy, the expectation is that the discourse of the 2olos will not feature more social and market-oriented discourse about fiscal stimulus policies than the discourse of the I99os. Instead, it should feature more discourse about fiscal consolidation justified with arguments about institutional commitments. Furthermore, following this argument, if during the 2oros the budget speeches do feature political justifications for fiscal stimulus policies, these are responses to the European country-specific recommendations, which are not exclusively about public deficit levels, but may at times also urge governments to for example improve social security provisions (D'Erman et al. 20I9). In our analysis, we therefore also investigate whether the policy choices made during the 2oros appeared first in the political platforms of the governing parties or in the European recommendations.

\section{Analysis}

5.1. Comparing the budget speeches of 1992-1998 with 2009-2017 period

Table I cross-tabs the frequencies of the justifications and the policy-types these refer to for the 1992-I997 and the 2009-20I7 speeches (for a precise list of the speeches coded, please see the Online Appendix). The data is based on the budget speeches of the relatively similar governments of the I990s and 20Ios, namely the Vranitzky III, IV and V (I990-I997), the Faymann I and II (2009-2016) and the Kern governments (2016-2017).

Table 1: Frequencies of justifications (rows) by policy reference (columns)

\begin{tabular}{|c|c|c|c|c|c|c|}
\hline \multicolumn{7}{|c|}{ 1992-1997 } \\
\hline & General policies & Consolidation & Flscal stimulus & European & Other & Total \\
\hline Social justific. & $13 \%$ & $4 \%$ & $5 \%$ & $2 \%$ & $0 \%$ & $25 \%$ \\
\hline Market & $6 \%$ & $0 \%$ & $2 \%$ & $1 \%$ & $0 \%$ & $9 \%$ \\
\hline Macro-economic & $17 \%$ & $4 \%$ & $4 \%$ & $5 \%$ & $0 \%$ & $30 \%$ \\
\hline National finances & $14 \%$ & $11 \%$ & $2 \%$ & $0 \%$ & $0 \%$ & $27 \%$ \\
\hline Int. commitmnts. & $5 \%$ & $1 \%$ & $1 \%$ & $2 \%$ & $0 \%$ & $9 \%$ \\
\hline Total & $55 \%$ & $21 \%$ & $14 \%$ & $9 \%$ & $1 \%$ & $100 \%$ \\
\hline \multicolumn{7}{|c|}{ 2009-2017 } \\
\hline & General policies & Consolidation & Fiscal stimulus & European & Other & Total \\
\hline Social justific. & $9 \%$ & $3 \%$ & $12 \%$ & $1 \%$ & $0 \%$ & $24 \%$ \\
\hline Market & $6 \%$ & $1 \%$ & $4 \%$ & $0 \%$ & $0 \%$ & $11 \%$ \\
\hline Macro-economic & $14 \%$ & $2 \%$ & $5 \%$ & $1 \%$ & $2 \%$ & $24 \%$ \\
\hline National finances & $15 \%$ & $16 \%$ & $4 \%$ & $1 \%$ & $1 \%$ & $37 \%$ \\
\hline Int. commitmnts. & $1 \%$ & $1 \%$ & $1 \%$ & $0 \%$ & $0 \%$ & $3 \%$ \\
\hline Total & $45 \%$ & $22 \%$ & $25 \%$ & $4 \%$ & $3 \%$ & $100 \%$ \\
\hline
\end{tabular}

Source: Authors' own coding of budget speeches 1992-1998 and 2009-2016 (see Appendix I for the list of speeches). N=2419 policy-justification statements ( $\mathrm{N}=1021$ for $1992-1997$ speeches, $\mathrm{N}=1398$ for 2009-2017 speeches). The reported percentages are rounded to 0 decimals. When above .50 the percentages are reported as rounded to the higher number, when under .50 they are reported as rounded to the lower number. The sums are calculated based on the original percentages. 
The expectation of governments entering a fiscal straightjacket during the 2oIos and having less autonomy than during the I99os to present and justify fiscal stimulus policies with political arguments, is clearly disconfirmed. In the 2009-20I7 period, social- and market-oriented justifications for fiscal stimulus policies constituted respectively $12 \%$ and $4 \%$ of the overall discourse, whereas during the $1992-1998$ period only $5 \%$ and $2 \%$. During the 2oros, budget speeches appear thus to be twice as much political as the speeches of the I99os.

In terms of the justifications emphasizing institutional responsibilities, these appear to be slightly more frequent in the 20I0s, with an overall share of $36 \%$ in the I990s and $40 \%$ in the 20IOs. In line with the evolution of public deficit levels (Figure I), the budgets of both time periods feature a considerable share of discourse about fiscal consolidation, which was needed to meet EU budgetary thresholds. Interestingly, however, in terms of justifications, during the 20IOs references to national finances are more frequent than during the 1990 s $(37 \%$ vs $28 \%$ ), reflecting the fact that during the years of the Eurozone crisis, debt and deficit levels were highly salient themes in public discourse (Karremans 2020; Hutter/ Kriesi 2019). During the I990s, instead, the justifications referring to international commitments appear more frequently than the 2010 , i.e. $9 \%$ vs $3 \%$, suggesting that during the 1990 os governments had a relatively stronger tendency in de-politicizing their budgets by referring to European commitments.

In both time periods, the budgets introduce measures to compensate for the negative socio-economic effects of tax increases and expenditure reductions. A remarkable difference, however, is that while in the roros the government is quite specific about such measures and justifies these with either socially- or market-oriented arguments, in the 1990s the government tends to speak in more general terms, stating that the despite the fiscal consolidation measures the budget does not neglect economic growth objectives. As exemplified by the following passage, for instance, the speech presenting the 2013 budget highlights that within its action of reducing the public deficit, the government remains committed to increasing public spending in education:

"The 2013 budget reflects the federal government's political priorities: The university billion provides universities with additional means for the upcoming performance agreement covering the period from 2013 to 2015 , e.g. through the new higher education area structural funds. Under this title, the universities receive an annual I50 million Euros, to be distributed on a performance basis. In addition, a further expansion of the universities of applied sciences is enabled through the offensive funds as the government finances additional places at these institutions". ${ }^{\text {I2 }}$

(Maria Fekter, Nationalrat, I6 October 2012, emphasis added)

In the I990s, instead, the government's discourse tends to be less specific about its actions to compensate for the contractionary effects of fiscal consolidation. In the following passage, for instance, the finance minister simply informs the audience that the budgetary policy aims to minimize the economic effects of the budgetary consolidation of the previous years.

"Fair competition, low inflation, investments in research and development, well-trained workers, first-class infrastructure, and the global development of markets are factors of success for our future. These factors of success and consensual values ought to be supported through economic policy measures. Ladies and gentlemen! Budgetary policy plays a decisive role in this regard. Today we can say that we have managed to minimize the negative economic effects of the budget consolidation and to restrict the temporary dampening of growth to 1996 ". ${ }^{13}$

(Rudolf Edlinger, Nationalrat, I8 September I997, emphasis added)

Rather than a reduction in political choices, the main difference between the budget speeches of the two time periods regards mainly the specificity with which governments present the measures by which they compensate for fiscal consolidation policies. While in the I990s there tends to be a more general discourse about economic growth, the discourse of the 2oros features a higher share of distinct fiscal stimulus policies. From a parliamentary point of view, in the 2oros there appears to be more clarity with regards to the measures pursued by the government.

I2 „Die politischen Schwerpunkte der Bundesregierung spiegeln sich im Budget 2013 wider: Durch die Universitätsmilliarde werden den Universitäten für die kommende Leistungsvereinbarung für die $\mathrm{Pe}-$ riode 2013 bis 2015 zusätzliche Mittel zur Verfügung gestellt, etwa im Wege der neuen Hochschulraum-Strukturmittel. Unter diesem Titel erhalten die Universitäten jährlich I50 Millionen $€$, die leistungsorientiert vergeben werden. Durch die Offensivmittel wird auch der weitere Ausbau des Fachhochschulsektors ermöglicht, indem der Bund zusätzliche Studienplätze an Fachhochschulen fördert."

I3 „Faire Wettbewerbsbedingungen, niedrige Inflationsraten, Investitionen in Forschung und Entwicklung, gut ausgebildete Mitarbeiter, erstklassige Infrastruktur, weltweite Erschließung von Märkten sind Erfolgsfaktoren für unsere Zukunft. Diese Erfolgsfaktoren und diese konsensfähigen Wertvorstellungen gilt es mit wirtschaftspolitischen Maßnahmen zu unterstützen. Meine sehr verehrten Damen und Herren! Die Budgetpolitik spielt dabei eine entscheidende Rolle. Wir können heute sagen, es ist uns gelungen, die negativen wirtschaftlichen Effekte der Budgetkonsolidierung zu minimieren und eine vorübergehende Dämpfung des Wachstums auf I996 zu beschränken." 
Finally, also in terms of the policies presented, in the I990s there is considerably more attention dedicated to European-level policies. Together with the frequencies of justifications emphasizing international commitments, this entails that in the I990s - compared to the 20IOs the government tends to present its policy more as an extension of international developments rather than as autonomous political choices. In the 2oros, instead, policy-choices tend to be presented more as autonomous decisions. To confirm this latter point, in the next sub-section we take a deeper look into whether such decisions originate from the domestic or the European agenda.

\subsection{Domestic agendas vs European recommendations (2009-2018)}

The country-specific recommendations of the European Council underwent an evolution during the 20Ios. While during the first part of the decade - i.e. the years of the Eurozone crisis - the recommendations focussed mostly on countries' public debt and deficit levels, from 2014 onwards they started gradually to target social policy goals, such as improving social provisions and ensuring access to education (Zeitlin/Vanhercke 2018). The policy-justifications of the Austrian budget speeches follow a relatively similar pattern, with institutional justifications for fiscal consolidation being more prominently present in the early 2oIos, while the budget speeches of April 2014 and October 2015 feature more discourse about expenditure increases and tax reductions. Figure 2 illustrates this pattern.

Figure 2: Shares of justifications presenting political policy-choices and fiscal consolidation

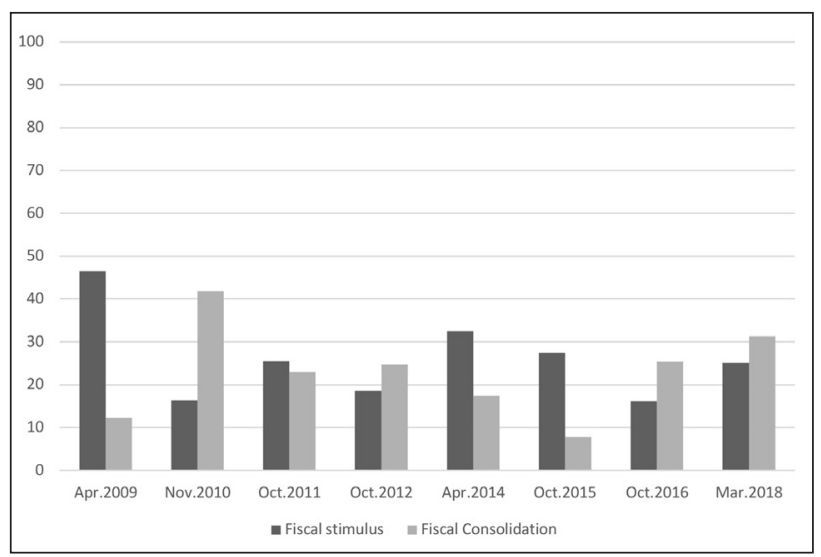

Source: Authors' own coding of the 2009-2018 budget speeches (see Appendix I). $\mathrm{N}=1561$ policy-justification statements

With the exception of the speech presenting the 2009 budget - during which the government had to justify its expenditure increases caused by the Great Recession the budgetary discourse of the years of the Eurozone crisis is largely focused on presenting fiscal consolidation measures. Between 2OII and 2013, discourse about fiscal consolidation is more prominent than discourse about expenditure increases and tax reductions. The trend reverses between 2014 and 2015, during which the budget speeches tend to be more focused on fiscal stimulus. Between 2017 and 2018, instead, discourse about fiscal consolidation tends to have again the upper hand.

The reversal of the trend between the 2OII-2OI3 and the 20I4-2015 periods corresponds partially to the socalled 'socialization of the European Semester' (Zeitlin/ Vanhercke 2018) by which - for most member states the Council's recommendations partially shift their focus from financial to societal matters. In the Austrian case, these recommendations featured seemingly contradictory policy-prescriptions, recommending both the continuation of a fiscal consolidation course as well as the improvement of social protection (Haas et al. 202O). Rather than autonomous policy-decisions, the fiscal stimulus policies introduced between 2014 and 2015 could thus be seen as an effort of adhering to these European demands. Yet, a deeper chronological analysis of the origins of the proposals for expenditure increases and tax reductions presented between 2014 and 2015 reveals that they are deeply rooted in the manifestos of the governing parties, and only partially related to the European recommendations. In addition, the return to a more extensive focus on fiscal consolidation in the 2016 and 2018 speeches seems to be driven by domestic political developments rather than by European recommendations.

Table 2 lists the most relevant fiscal stimulus policies presented in the Austrian budget speeches between 2009 and 2018, and tracks whether these measures were present in the most recent country-specific recommendations and party-manifestos.

The expenditure increases and reductions in taxation introduced by Austrian governments during the 20Ios are partially in line with the European country-specific recommendations. At the same time, they are all traceable back to the political programmes of the governing parties. In most instances the policy-proposals contained in the party manifestos are antecedent to the recommendations issued by the Council. This confirms earlier findings that governments incorporate the Council's recommendations when these are in line with the preferences of the coalition parties (Eihmanis 2018; Karremans 2020). Furthermore, when country-specific recommendations are about policies that do not meet the preferences of the governing parties, these do not seem to enter the government's agenda (for a full overview of the country-specific recommendations, please see consult Table A2 in the Appendix). This is the case of for example the recommendation to increase the retirement age: to date, no significant initiative has been undertaken in this regard. 
Table 2: Fiscal stimulus policies and matching Council recommendations and manifesto-pledges

\begin{tabular}{|c|c|c|c|}
\hline Policy & Year of speech & $\begin{array}{l}\text { Matching Council } \\
\text { recommendations }\end{array}$ & Matching party manifesto pledges \\
\hline $\begin{array}{l}\text { Tax reform (volume: EUR } 3.2 \text { billion): } \\
\text { more people taken out of tax altogether; } \\
\text { new credits and exemptions for families; } \\
\text { funded by expenditure reductions and } \\
\text { administrative reforms; tax ratio brought } \\
\text { down to } 41.2 \%\end{array}$ & 2009 & $\begin{array}{l}\text { n/a (prior to European } \\
\text { Semester) }\end{array}$ & $\begin{array}{l}\text { SPÖ: prepone payroll tax reform to } \\
2009 \text { and focus on low- and middle- } \\
\text { income earners } \\
\text { ÖVP: tax reform comprising EUR } 3 \\
\text { billion (middle class and families), } \\
\text { funded by spending cuts/admi- } \\
\text { nistrative reforms; tax ratio < } 40 \%\end{array}$ \\
\hline $\begin{array}{l}\text { Education spending was partially } \\
\text { shielded from austerity and actually saw } \\
\text { its budget increase in order to pay for } \\
\text { various measures and programs, such as } \\
\text { all-day childcare in schools, smaller class }\end{array}$ & 2010 & $\begin{array}{l}n / a \text { (prior to European } \\
\text { Semester) }\end{array}$ & $\begin{array}{l}\text { SPÖ: promote all-day schooling, } \\
\text { smaller class sizes, and combination } \\
\text { of apprenticeship with matriculation } \\
\text { ÖVP: improve availability of childcare, } \\
\text { including during the afternoon }\end{array}$ \\
\hline
\end{tabular}

Continue to increase investment in education (comprehensive schools, smaller class sizes, all-day childcare)

2011 Recommendation \#4: improve availability of all-day school places

2012 Recommendations \#3, \#4 and \#5: increase employment rates for older persons and women; improve educational outcomes for (disadvantaged) young people

2014 Recommendation \#5 (2013*): improve educational outcomes in early childhood and strategic planning in higher education; reduce drop-outs.

Tax reform: cut the introductory tax rate to $25 \%$ (from $36,5 \%$ ), among other measures, in a fiscally responsible way

Infrastructure: increase investment by EUR 800 million until the next year

Less taxation: reduce tax ratio to $40 \%$ until 2022; lower the tax burden for families (max. amount of relief: EUR 1500 per child); cut value added tax (tourism) from 13 to $10 \%$; abolish the rental contract fee
2015 Recommendation \#1: reform aimed at reducing tax burden on labour should be budgetneutral

$2016 \quad n / a$

$2018 \quad n / a$
Both parties: all-day childcare in schools as a middle way between SPÖ and ÖVP proposals (see above) SPÖ: promote comprehensive schools for 10- to 14-year-olds and smaller class sizes

SPÖ: promote all-day schooling, smaller class sizes, and combination of apprenticeship with matriculation ÖVP: improve availability of childcare, including during the afternoon

Both parties: second year of kindergarten free of charge

Both parties: lower the introductory tax rate, reduce burden on labour

Both parties: more investment in infrastructure

ÖVP: lower taxes for families by up to EUR 1500

FPÖ: abolition of the rental contract fee Both parties: reduce tax ratio in the direction of $40 \%$; cut tourism VAT from 13 to $10 \%$

*2014 budget was presented prior to publication of the Council's recommendations for the same year. 
While being partially in line with the European country-specific recommendations, the political choices about fiscal stimulus policies made by the governments during the 20Ios seem to originate mostly from the political programmes of the governing parties. Furthermore, this is also true for the accent placed on fiscal consolidation under the Kurz I government. Even though the reduction of debt and deficit levels is generally in line with European budgetary recommendations, the accent placed on this policy-direction under the Kurz I government clearly outweighs the recommendations of the Council. The change of budgetary discourse between the Kern and Kurz I governments, therefore, strongly suggest that the partisan composition of government is still highly relevant for budgetary policy in Austria.

\section{Conclusion}

This paper started with a quote from the budget speech of March 2018, which highlighted how the Austrian government managed to perform a budgetary surplus. Based on scholarly arguments about how recent budgetary reforms are a sign of governments entering a straightjacket in which they have no decision-making autonomy (Schäfer/Streeck 2013; Scharpf 20II), we raised the question whether governments still have the room for discussing and pursuing different political alternatives, or whether instead budgetary policy has become simply about complying with institutional commitments. Our results indicate that governments still make relatively autonomous choices regarding their budgetary policies, and shed therefore new light onto the question of the power balance between politics and state bureaucracy (Biegelbauer et al. 2015). The comparison with the I990s shows that the share of ideological arguments in finance ministers' budget speeches has not diminished. Furthermore, compared to the I990s, the budget speeches of the 2010 seem to be more detailed about the policies pursued by the government. This entails that the parliament receives better information about the government's taxation and expenditure policies. In this regard, the quality of the democratic feedback loop seems to have improved rather than worsened.

Furthermore, this paper also dealt with the question whether the Austrian government makes its political decisions about expenditure and taxation autonomously, or whether instead these decisions are simply a response to European country-specific recommendations. While it is true that a considerable part of the political choices made during the 2oros overlap with these recommendations, we find that these measures are often first proposed in the party manifestos of the governing parties. In addition, we find that when the European recommendations are not in line with the preferences of the coalition parties, these tend not to be incorporated in the government's policy agenda. This finding strengthens recent insights about the formulation and implementation of the European country-specific recommendations being largely dependent on the political preferences of the national governments (Eihmanis 2018; Karremans 2020; Maricut/Puetter 2018).

Finally, this paper sheds new light into how result-oriented budgetary processes and the involvement in multilevel governance affect the relations between government and parliament. Rather than obscuring budgetary decisions with de-politicized justifications about institutional commitments, in the Austrian case the new budgetary policy-making procedure seems to have had the effect to induce governments to provide more precise information to the parliament about its budgetary choices. Interestingly, this outcome was among the objectives of the state-bureaucrats designing the reforms in the early 2000 (Meszarits/Seiwald 2008). The result-oriented approach of the Austrian budgetary process also characterizes the budgetary cycle in the European Semester (Verdun/Zeitlin 2018), which obliges governments to pre-define the objectives of their policies. The pre-definitions of these objectives need in turn to be communicated to the parliament, which therefore is better informed about the criteria and purposes of how governments use their taxing and spending powers. The impact of the European Semester on national democracy needs therefore to be seen also through this lens, namely through the quality of the information by which governments inform the national parliaments about their budgetary choices.

\section{References}

Bekker, Sonja (2016), Is There Flexibility in the European Semester Process? Exploring Interactions between the EU and Member States within Post-Crisis Socio-Economic Governance, SSRN Scholarly Paper ID 2743238, Internet: https://papers.ssrn.com/ abstract $=2743238$ (access: $18.02 .202 \mathrm{I})$.

Biegelbauer, Peter/Christoph Konrath/Benedikt Speer (2015), Die wissenschaftliche (Nicht-)Beschäftigung mit der Verwaltung und ihrem Verhältnis zur Politik in Österreich', in: Österreichische Zeitschrift für Politikwissenschaft, Vol.43(4), 349-65.

Brandtner, Christof/Markus Kinschner/Tobias Polzer (2013), Unternehmen Österreich? Wirkungsorientierung am Grat zwischen Technokratie und Demokratie, in: Momentum Quarterly - Zeitschrift für sozialen Fortschritt, Vol. 2(4), 208-230.

Crum, Ben (2013), Saving the Euro at the Cost of Democracy?, in: JCMS: Journal of Common Market 
Studies, Vol. 5I(4), 6I4-630, Internet: https://doi. org/IO.IIII/jcms.I2OI9.

Damhuis, Koen/Johannes Karremans (2017), Responsive to Whom? A comparison of the Mitterrand and Hollande presidencies, in: West European Politics, Vol. 4O(6), I267-I287, Internet: https://doi.org/IO.IO80/oI 402382.2017.1300472.

D’Erman, Valerie/Jörg Haas/Daniel F. Schulz/Amy Verdun (2019), Measuring Economic Reform Recommendations under the European Semester: 'One Size Fits All' or Tailoring to Member States?, in: Journal of Contemporary European Research, Vol. I5(2), I94-2II, Internet: https://doi.org/IO.30950/jcer.vi5i2.999.

Doray-Demers, Pascal/Martial Foucault (2017), The Politics of Fiscal Rules within the European Union: A Dynamic Analysis of Fiscal Rules Stringency, in: Journal of European Public Policy, Vol. 24(6), 852-870, Internet: https://doi.org/I0.IO80/1350I763.20I7.1296 883.

Eihmanis, Edgars (2018), Cherry-Picking External Constraints: Latvia and EU Economic Governance, 2008-2014, in: Journal of European Public Policy, Vol. 25(2), 23I-249, Internet: https://doi.org/IO.IO80/I350 I763.2017.1363267.

Ennser-Jedenastik, Laurenz (2020), The FPÖ's Welfare Chauvinism, in: Österreichische Zeitschrift Für Politikwissenschaft, Vol. 49(I), I-I3, Internet: https://doi.org/ I0.15203/ozp.3102.vol49issI.

Fischer, Hans Georg (200I), Die verstärkte Zusammenarbeit nach dem Amsterdamer Vertrag - Option für eine differenzierte Integration in der Europäischen Union, in: Wilfried Loth (Hrsg.), Das europäische Projekt zu Beginn des 2I. Jahrhunderts, Opladen: Leske \& Budrich, 203-224.

Haas, Jörg S./Valerie J. D'Erman/Daniel F. Schulz/Amy Verdun (2O20), Economic and Fiscal Policy Coordination after the Crisis: Is the European Semester Promoting More or Less State Intervention?, in: Journal of European Integration, Vol. 42(3), 327-344, Internet: https:// doi.org/10.1080/07036337.2020.1730356.

Hutter, Swen/Hanspeter Kriesi (2019), European Party Politics in Times of Crisis, Cambridge: Cambridge University Press.

Karremans, Johannes (2020), 'Political alternatives under European economic governance: evidence from German budget speeches (2009-2019), in: Journal of European Public Policy, Online First: DOI: I0.1080/13501763.2020.1748096.

Karremans, Johannes/Koen Damhuis (2020), 'The changing face of responsibility: A cross-time comparison of French social democratic executives', in: Party Politics, Vol. 26(3), 305-316, Internet: https://doi. org/IO.I177/1354068818761197.

Karremans, Johannes/Zoe Lefkofridi (2020), 'Responsive versus responsible? Party democracy in times of crisis', in: Party Politics, Vol. 26(3), 27I-279, Internet: https://doi.org/IO.II77/I35406881876II99.

Kriesi, Hanspeter/Edgar Grande/Martin Dolezal/Marc Helbling/Dominic Höglinger/Swen Hutter/Bruno Wüest (2012), Political Conflict in Western Europe, Cambridge: Cambridge University Press.

Laffan, Brigid (20I4), Testing Times: The Growing Primacy of Responsibility in the Euro Area, in: West European Politics, Vol. 37(2), 270-287, Internet: https://doi.or g/IO.IO80/OI 402382.2014.887875.

Mair, Peter (2013), Bini Smaghivs. the Parties: Representative Government and Institutional Constraints, in: Schäfer, Armin/Wolfgang Streeck (eds.), Politics in the Age of Austerity, Cambridge: Polity Press, I43-I68.

Mair, Peter (2014), Representative versus Responsible Government, in: Biezen, Ingrid van (ed.), On Parties, Party Systems and Democracy: Selected Writings of Peter Mair, Colchester: ECPR Press, 58I-596.

Maricut, Adina/Uwe Puetter (2018), Deciding on the European Semester: The European Council, the Council and the Enduring Asymmetry between Economic and Social Policy Issues, in: Journal of European Public Policy, Vol. 25(2), 193-21I, Internet: https://doi.org/IO .I080/13501763.2017.136327I.

Mariotto, Camilla/Fabio Franchino (2020), L'attuazione Delle Raccomandazioni Specifiche All'Italia Dal 2002 al 2018, in: Rivista Italiana Di Politiche Pubbliche, no. 2/202O, Internet: https://doi.org/IO.I483/98085.

Meszarits, Veronika/Johann Seiwald, (2008), Budgetary Reform in Austria: Towards Tighter Coupling within the Financial and Management System, Working Paper 3/2008, Austrian Federal Ministry of Finance, Internet: https://www.researchgate.net/publication/ 242719394_Budgetary_Reform_in_Austria_Towards_tighter_coupling_within_the_financial_ and_management_system (access: 18.02.202I).

Nauschnigg, Franz (1992), Die EG auf dem Weg zur Wirtschafts- und Währungsunion: Auswirkungen auf Österreich, in: Wirtschaft und Gesellschaft, Vol. I8(3), 34I-356.

OECD (2018), Budgeting in Austria, in: OECD Journal on Budgeting, Vol. I8(I), Internet: https://doi.org/IO.I787/ budget-I8-5j81804wgokf.

Powell, G. Bingham (2004), The Quality of Democracy: The Chain of Responsiveness, in: Journal of Democra$c y$, Vol. 15(4), 9I-IO5, Internet: https://doi.org/IO.1353/ jod.2004.0070.

Praprotnik, Katrin (2017), Parteien und ihre Wahlversprechen: Einblicke in die Politikgestaltung in Österreich, Wiesbaden: Springer VS.

Rodrik, Dani (2000), How Far Will International Economic Integration Go?, in: Journal of Economic Perspectives, Vol. I4(I), I77-I86, Internet: https://doi. org/IO.I257/jep.I4.I.I77. 
Rose, Richard (20I4), Responsible Party Government in a World of Interdependence, in: West European Politics, Vol. 37(2), 253-269, Internet: https://doi.org/IO.IO80/ OI4O2382.2OI4.887874.

Schäfer, Armin/Wolfgang Streeck (eds.) (2013), Politics in the Age of Austerity, Cambridge: Polity Press.

Scharpf, Fritz W. (201I), Monetary Union, Fiscal Crisis and the Preemption of Democracy, SSRN Scholarly Paper ID 1852316, Internet: https://papers.ssrn.com/ abstract $=1852316$ (access: $18.02 .202 \mathrm{I})$.

Schick, Allen (2003), Does Budgeting Have a Future?, in: OECD Journal on Budgeting, Vol. 2(2), 7-48, Internet: https://doi.org/ro.1787/budget-v2-art8-en.

Schmidt, Manfred G. (1996), When Parties Matter: A Review of the Possibilities and Limits of Partisan Influence on Public Policy, in: European Journal of Political Research, Vol. 30(2), I55-183, Internet: https://doi. org/IO.IIII/j.I475-6765.I996.tboo673.x.

Schmidt, Vivien A. (2008), Discursive Institutionalism: The Explanatory Power of Ideas and Discourse, in: Annual Review of Political Science, Vol. II(I), 303-326, Internet: https://doi.org/IO.II46/annurev.polisci.II. 060606.I35342.

Schmidt, Vivien A. (2020), Europe's Crisis of Legitimacy: Governing by Rules and Ruling by Numbers in the Eurozone, Oxford: Oxford University Press.

Schoubroeck, Thierry van/Jean-Jacques Lennon/Mathieu Saunier/Eleonora Kist (2019), Aligning the budget with the Performance-Based budgeting: lessons from Member States, Internet: https://www.europarl.europa.eu/RegData/etudes/STUD/2019/621802/IPOL STU(2019)621802_EN.pdf (access: 18.02.202I).

Steger, Gerhard (2010), Austria's Budget Reform: How to Create Consensus for a Decisive Change of Fiscal Rules, in: OECD Journal on Budgeting, Vol. IO(I), I-I4, Internet: https://doi.org/IO.I787/budget-IO-5kmh5hcrx924.

Steger, Gerhard (2012), Budget Reform in Austria: From Traditional to Modern Budgeting, in: Presupuesto y Gasto Público, 69, I47-I62.

Truchlewski, Zbigniew (2020), 'Oh, What a Tangled Web We Weave': How Tax Linkages Shape Responsiveness in the United Kingdom and France, in: Party Politics, Vol. 26(3), 280-290, Internet: https://doi. org/IO.II77/I3540688187640I7.

Veen, A. Maurits van der (20II), Ideas, Interests and Foreign Aid, Cambridge: Cambridge University Press.

Verdun, Amy/Jonathan Zeitlin (2018), Introduction: The European Semester as a New Architecture of EU Socioeconomic Governance in Theory and Practice, in: Journal of European Public Policy, Vol. 25(2), I37-I48, Internet: https://doi.org/IO.I080/13501763.2017.1363807.
Zeitlin, Jonathan/Bart Vanhercke (2018), Socializing the European Semester: EU Social and Economic Policy Co-Ordination in Crisis and Beyond, in: Journal of European Public Policy, Vol. 25(2), I49-I74, Internet: https://doi.org/IO.IO80/1350I763.2017.1363269.

\section{Authors}

Johannes Karremans is Post-doctoral researcher at the University of Salzburg, holding a Lise Meitner grant from the Austria Science Fund with the project entitled "Responsive versus responsible: A comparative study of budgetary discourse in the Eurozone". Dr Karremans holds a PhD from the European University Institute (2017). His research has appeared in West European Politics, Party Politics and the Journal of European Public Policy. ORCID: https://orcid.org/oooo-00o2-8770-374X

Johann Kaltenleithner is an MA student at the University of Salzburg and the University of Linz, with an interest in European integration theory and political philosophy. 


\section{APPENDIX}

\section{List of speeches coded and coding procedure}

Tables A1 lists the speeches that were coded in the analysis presented in the paper 'Is Austrian Budgetary Policy Still "Political"? A Cross-Time Comparison of Budget Speeches', providing information on the date, the name of the finance minister delivering the speech, the location, and the number of policy-justifications collected per speech.

Table A1: Speeches coded

\begin{tabular}{|c|c|c|c|}
\hline Date speech & Speaker & Location & $\mathrm{N}$ observations \\
\hline 22.10 .1992 & Ferdinand Lacina & Nationalrat, Vienna & 154 \\
\hline 20.10.1993 & Ferdinand Lacina & Nationalrat, Vienna & 190 \\
\hline 09.03.1995 & Ferdinand Lacina & Nationalrat, Vienna & 171 \\
\hline 20.03.1996 & Viktor Klima & Nationalrat, Vienna & 286 \\
\hline 18.09.1997 & Rudolf Edlinger & Nationalrat, Vienna & 220 \\
\hline 21.04.2009 & Josef Pröll & Nationalrat, Vienna & 172 \\
\hline 30.11 .2010 & Josef Pröll & Nationalrat, Vienna & 189 \\
\hline 19.10.2011 & Maria Fekter & Nationalrat, Vienna & 240 \\
\hline 16.10.2012 & Maria Fekter & Nationalrat, Vienna & 210 \\
\hline 29.4.2014 & Michael Spindelegger & Nationalrat, Vienna & 166 \\
\hline 14.10.2015 & Hans Jörg Schelling & Nationalrat, Vienna & 204 \\
\hline 12.10 .2016 & Hans Jörg Schelling & Nationalrat, Vienna & 217 \\
\hline 21.3.2018 & Hartwig Löger & Nationalrat, Vienna & 163 \\
\hline
\end{tabular}

The data collection was carried out with the help of two student assistants. The coding procedure involved identifying the policies presented in the speech, and gathering the arguments justifying each policy. Each argument justifying a policy constitutes one observation, is was categorized according to policy-type and justification-theme. At the beginning of the work-procedure, several passages from diverse speeches were coded by Johannes Karremans and the two students, until a $90 \%$ overlap was reached. This exercise was carried out also in subsequent stages of the coding procedure. Overall, all budget speeches were coded independently by Johannes Karremans and at least one student assistant, with an average overlap of $80 \%$, with non-overlaps generally regarding statements that require in-depth sectorial knowledge. Final decisions on the coding of doubtful cases were done by Johannes Karremans. 


\section{APPENDIX II}

Table A2: European Council's country-specific recommendations for Austria, 2011-2017

\begin{tabular}{|c|c|c|}
\hline & Summary of Recommendations & Years* \\
\hline \multirow{3}{*}{$\begin{array}{l}\text { Financially-focussed } \\
\text { recommendations }\end{array}$} & Correct the excessive deficit & $2011,2012,2013,(2014)$ \\
\hline & $\begin{array}{l}\text { Pursue structural adjustment efforts towards the medium-term objective } \\
\text { (MTO)/avoid deviations from the MTO. }\end{array}$ & $\begin{array}{l}\text { 2011, 2012, 2013, 2014, } \\
2015,2016,2017\end{array}$ \\
\hline & $\begin{array}{l}\text { Do not lose sight of the budgetary impact of healthcare, e. g. by } \\
\text { aligning responsibilities, implementing recent reforms and ensuring the } \\
\text { sustainability of the system. }\end{array}$ & $\begin{array}{l}\text { 2011, 2012, 2013, 2014, } \\
\text { 2016, } 2017\end{array}$ \\
\hline \multirow[t]{6}{*}{$\begin{array}{l}\text { Socially-focussed } \\
\text { recommendations }\end{array}$} & $\begin{array}{l}\text { Improve the sustainability of the pension system/raise the effective } \\
\text { retirement age, preferably by harmonizing the statutory retirement age for } \\
\text { men and women or linking it to life expectancy. }\end{array}$ & $\begin{array}{l}2011,2012,2013,2014 \\
2015,2016,(2017)\end{array}$ \\
\hline & $\begin{array}{l}\text { Various supplementary pension-related proposals, such as ensuring the } \\
\text { success of recently passed restrictions on early retirements and improving } \\
\text { the employability of older workers. }\end{array}$ & 2011, 2012, 2013, 2014 \\
\hline & $\begin{array}{l}\text { Step up efforts to increase the labour market participation of women/other } \\
\text { relevant demographic groups, such as people with a migrant background, } \\
\text { including through improving childcare, long-term care services, recognition } \\
\text { of qualifications and educational outcomes. }\end{array}$ & $\begin{array}{l}\text { 2011, 2012, 2013, 2014, } \\
2015,2016,2017\end{array}$ \\
\hline & $\begin{array}{l}\text { Taxation/social security: Shift the burden away from low-income earners, } \\
\text { or labour in general, towards less growth-suppressing sources, such as } \\
\text { property, and do so in a budget-neutral way. }\end{array}$ & $\begin{array}{l}\text { (2011), 2012, 2013, 2013, } \\
2014\end{array}$ \\
\hline & $\begin{array}{l}\text { Improve educational outcomes, in particular of disadvantaged young } \\
\text { people (such as those with a migrant background), e. g. by enhancing early } \\
\text { childhood education and reducing negative effects of early tracking. }\end{array}$ & $\begin{array}{l}\text { 2012, 2013, 2014, 2015, } \\
2016,2017\end{array}$ \\
\hline & Improve strategic planning in higher education; reduce drop-outs. & (2012), 2013, 2014 \\
\hline \multirow[t]{3}{*}{$\begin{array}{l}\text { Market-focussed } \\
\text { recommendations }\end{array}$} & $\begin{array}{l}\text { Take various pro-competition measures, e. g. strengthen the federal } \\
\text { competition authority; remove excessive barriers for service providers. }\end{array}$ & $\begin{array}{l}\text { 2011, 2012, 2013, 2014, } \\
2015,2016,2017\end{array}$ \\
\hline & Continue to restructure and oversee the (partly) nationalised banks. & 2012, 2013, 2014 \\
\hline & $\begin{array}{l}\text { "Address the potential vulnerabilities of the financial sector in terms of } \\
\text { foreign exposure and insufficient asset quality." }\end{array}$ & 2015 \\
\hline
\end{tabular}

*Years in parentheses indicate partial applicability. 